\title{
Berry Characterisation of cv Shiraz According to Position on the Rachis
}

\author{
A. Pisciotta ${ }^{1 *}$, R. di Lorenzo ${ }^{1}$, M.G. Barbagallo ${ }^{1}$, J.J. Hunter ${ }^{2,3}$ \\ (1) Palermo University, Department S.A.F. - Viale delle Scienze, 11, Edificio 4, Ing. H, 90128-Palermo \\ (2) ARC Infruitec-Nietvoorbij ${ }^{1}$, Private Bag X5026, 7599, Stellenbosch, South Africa \\ (3) Stellenbosch University, Department of Viticulture and Oenology, Private Bag XI, Matieland 7602, South Africa.
}

Submitted for publication: December 2012

Accepted for publication: February 2013

Key words: Shiraz, berry variability, berry position, berry weight, berry composition

\begin{abstract}
In this study, characterisation of the physical and compositional parameters of berries located in different positions on the rachis of Shiraz/R99 bunches was done. Berries were divided according to position on the rachis (apical, median and basal) and berry weight, resulting in four berry weight classes, averaging $0.86 \mathrm{~g}, 1.29 \mathrm{~g}, 1.74 \mathrm{~g}$ and $2.26 \mathrm{~g}$ and $0.74,1.18,1.59$ and $2.09 \mathrm{~cm}^{3}$, respectively. The berries were analysed individually. The fresh weight of the berries comprised approximately $4 \%$ seeds, $20 \%$ skin and $76 \%$ flesh. Different percentage distributions were found for each class of berry weight and according to position on the rachis. From the top to the bottom rachis position, an increase in skin proportion value and a decrease in flesh and seed proportion value occurred. Skins decreased and flesh increased in proportion from the smallest to the largest berry size. The seed maintained a relatively stable proportion, irrespective of berry size. Larger berries had more flesh compared to skin than smaller berries. A higher level of soluble solids occurred in the shoulder to middle bunch area $\left(28.7^{\circ} \mathrm{B}\right.$ and $28.6^{\circ} \mathrm{B}$, respectively) than in the bottom area $\left(27.6^{\circ} \mathrm{B}\right)$. It is extremely difficult to obtain uniform berry size and composition under field conditions. Continuous efforts are required to reduce variation and the potential negative impact on wine quality and consistency of wine style.
\end{abstract}

\section{INTRODUCTION}

The physical and chemical variation between berries from any given vineyard seems not to be considered seriously by many grape growers and winemakers. Although management practices generally aim to minimise variation in the vineyard, the existence of berry variation is often ignored entirely (Hunter et al., 2010). Variation between and within bunches obviously affects sampling strategy (Di Lorenzo et al., 2007; Tarter \& Keuter, 2008; Barbagallo et al., 2011), grape composition, and wine style (Sousa de Melo, 2011). Uneven berry development and its impact on wine quality are largely undocumented.

In the vineyard, different forms of variation in grape quality may occur: from vine to vine, from shoot to shoot, between bunches, and between berries. This variation may result from vineyard heterogeneity, including differences in soil characteristics, young vine establishment, graft combination, plant material quality, node number, shoot number, bunch number, bunch position, microclimate, etc. (Baker et al., 1965; Hunter et al., 2010). Variation may be minimised by site selection (and most importantly by choosing a site that is well demarcated with limited variation in the soil), judicious pruning practices and canopy management (Hunter et al., 2010).

The variables that may contribute to variation among bunches include inflorescence primordia size, flower number, fruit set, berry number, berry volume and, notably, bunch position (Shaulis, 1956; Smart, 1985, Carbonneau et al., 1991; Pisciotta et al., 2010, 2012). According to Smart (1985), variation among berries is poorly understood. Although the factor(s) leading to the occurrence of berry variation are not yet clearly identified, variation is manifested in berry size, berry composition, seed number, and seed size (Olmo, 1946; Kasimatis et al., 1975; Di Lorenzo et al., 1991; Ummarino \& Di Stefano, 1996; Trought et al., 1997; Pisciotta et al., 2010; Barbagallo et al., 2011; Pisciotta et al., 2012). Factors that may contribute include the following: variation in bunch architecture; relationship between seed, pulp and skin development; cell division and expansion; role of vascular function in berry growth and development

\footnotetext{
${ }^{1}$ The Fruit, Vine and Wine Institute of the Agricultural Research Council
}

*Corresponding author: E-mail: antonino.pisciotta@unipa.it

Aknowledgements: The authors gratefully acknowledge the technical assistance of the personnel of the Viticulture Department at the ARC Infruitec-Nietvoorbij, Stellenbosch, as well as financial support from the Agricultural Research Council of South Africa and the South African Wine Industry (through Winetech) 
(Fernandez et al., 2006; Gray, 2006); berry position on the rachis (Tarter \& Keuter, 2005); sun exposure; pollination of individual flowers (Trought et al., 1997); flower and inflorescence size; and progress of the setting and further development processes (Poni et al., 2008). A typical berry follows a double-sigmoid growth curve during its postflowering development (Coombe, 1987), but two berries in the same cluster may follow quite different paths (Matthews et al., 1987; Pisciotta et al., 2010, 2012). The divergence of the growth curves becomes apparent shortly after flowering and the timing of this divergence is responsible for the extent of the differences between berries at harvest (Pisciotta et al., 2012).

The specification of grape quality would require physical (berry size, seed hardness, skin and pulp integrity, etc.), biological (incidence and severity of diseases) and chemical (sugar, acidity, pH, anthocyanins, phenolics, tannin, aroma precursors, flavour, etc.) aspects of the grape to be considered, but these are difficult to control from season to season (Greenspan, 2005) and would certainly further complicate the quest to limit variation, to produce the required wine quality, to identify different wine styles, and to produce consistent wine styles.

Although zonal/differential management and harvesting are appropriate techniques for managing the variation that occurs in the vineyard, neither the origin of variation nor the variation in grape composition and ripening are fully addressed; this may clearly occur over a multitude of scales.

The broad objective of this study was to determine whether the position of the berry on the rachis would affect the physical and compositional parameters of the berry. Different berry categories were also included.

\section{MATERIALS AND METHODS \\ Vineyard}

Grapes from a nine-year-old Vitis vinifera L. cv. Shiraz (clone SH1A) vineyard, grafted onto Richter 99 (Vitis berlandieri $\mathrm{x}$ Vitis rupestris) (clone RY2A), were used. The vineyard is located at the Experimental Farm of the ARC InfruitecNietvoorbij at Stellenbosch (Western Cape, South Africa). The area is within a Mediterranean climate. The vines are spaced $2.75 \mathrm{~m} \times 1.5 \mathrm{~m}$ on a Glenrosa soil (Soil Classification Working Group, 1991) with a western aspect (26 slope) and trained onto a seven-wire (cordon wire and three sets of movable wires) lengthened Perold (vertical shoot positioned) trellising system (Zeeman, 1981). Rows were oriented North-South. Vines were micro-sprinkler irrigated at the pea size and véraison stages (12 hours at $32 \mathrm{~L} / \mathrm{h})$. The vines were pruned to two-bud spurs, with a spur spacing of approximately $15 \mathrm{~cm}$ in a double cordon. Rye was used as cover crop during the winter. Normal cultivation practices for the production of healthy grapes were used.

\section{Measurements}

One typical bunch per vine was selected from eight vines according to appearance, ampelography, similar exposure (diffused sunlight) conditions and being representative of the vineyard (Di Lorenzo et al., 2007). These bunches contained a total of 911 berries, of which every single berry was analysed individually. Sampling was done on 13 March
2007 (full ripeness stage) and the berries were divided according to position on the rachis (apical, median and basal, by dividing the total rachis length into thirds). Berries on the wings were classified according to the length of the rachis axis (divided into thirds). Harvested grapes were cooled to the same temperature $\left(20^{\circ} \mathrm{C}\right)$ before processing. Each one of the berries was analysed for must total soluble solids (Brix) (by means of a refractometer), mass (g), volume $\left(\mathrm{cm}^{3}\right)$ (determined by graduate cylinder), skin mass (g), skin surface $\left(\mathrm{cm}^{2}\right)$ (measured with a LICOR LI 3100 area meter), number of seeds per berry, and total seed mass (g). The percentage distribution of skin, pulp and seed (mass basis), the skin:pulp ratio, and berry skin surface $\left(\mathrm{cm}^{2}\right)$ :berry volume $\left(\mathrm{cm}^{3}\right)$ ratio were calculated. The variation in the total number of berries per rachis position (a third) was calculated for all the parameters. After all the berries had been processed, four different berry classes were selected according to berry weight $(\mathrm{g})$. The four berry classes were as follows: 1 ( $\leq 1.0 \mathrm{~g}$ ); 2 (between $1.01 \mathrm{~g}$ and $1.50 \mathrm{~g}$ ); 3 (between $1.51 \mathrm{~g}$ and $2.0 \mathrm{~g}$ ) and $4(>2.0 \mathrm{~g})$.

\section{Statistics}

A statistical data analysis was performed by ANOVA regression analysis, taking into account rachis position (top, middle, bottom) as category variables and berry weight classes $(1,2,3,4)$ as quantitative variables. Each berry was treated as an experimental unit. For each weight category and rachis position, the coefficient of variation of berry weight was also calculated. All statistical analyses were performed using SYSTAT $9^{\circledR}$.

\section{RESULTS AND DISCUSSION}

The apical third of the rachis had the most berries (43\%) of the total bunch, followed by the middle $(37.8 \%)$ and bottom (19.2\%) parts.

This distribution reflected the bunch structure of Shiraz, with the wings having a role in determining the number of berries of a particular part of the bunch. Dividing the berries according to weight into four classes showed classes 2 and 3 being the best represented in the entire sample (38.1\% and $37.9 \%$ respectively), whereas the smallest and largest berries (classes 1 and 4 respectively) were less well represented (7.2 \% and $16.8 \%$, respectively; Table 1 ).

All four berry size categories were better represented in the top and middle part of the rachis. The average weight of the different berry classes was $0.86 \mathrm{~g}, 1.29 \mathrm{~g}, 1.74 \mathrm{~g}$ and $2.26 \mathrm{~g}$ respectively for classes 1, 2, 3 and 4, therefore differing by 0.43 to $0.50 \mathrm{~g}$. Moreover, except for classes 3 and 4 ( 8 to $9 \%)$, the coefficient of variation was similar for all categories (from $10 \%$ to $16 \%$; Table 2).

The fresh weight of the berries comprised of approximately $4 \%$ seeds, $20 \%$ skin and $76 \%$ flesh. A different percentage distribution was found for each category size and berry position along the rachis (Table 3 ).

From the top to the bottom rachis position there was an increase in skin proportion value and a decrease in flesh and seed proportion value. Different berry classes showed different proportions of skin, seed and flesh, with the skins decreasing and the flesh increasing in proportion from class 1 to class 4 . The seeds maintained a relatively stable 
TABLE 1

Berry percentage distribution for each category size and position. For each category size, the percentage of berry number (first column) is based on total berries $(n=911)$, whereas percentage of berries per class (second column) is based on total berries per single category size.

\begin{tabular}{|c|c|c|c|c|c|c|c|c|c|}
\hline Size category & \multicolumn{2}{|c|}{1} & \multicolumn{2}{|c|}{2} & \multicolumn{2}{|c|}{3} & \multicolumn{2}{|c|}{4} & Total \\
\hline Rachis position & $\begin{array}{c}\% \text { of } \\
\text { berry } \\
\text { number }\end{array}$ & $\begin{array}{c}\% \% \text { of } \\
\text { berries } \\
\text { per class }\end{array}$ & $\begin{array}{c}\% \text { of } \\
\text { berry } \\
\text { number }\end{array}$ & $\begin{array}{c}\% \text { of } \\
\text { berries } \\
\text { per class }\end{array}$ & $\begin{array}{c}\% \text { of } \\
\text { berry } \\
\text { number }\end{array}$ & $\begin{array}{c}\% \text { of } \\
\text { berries } \\
\text { per class }\end{array}$ & $\begin{array}{c}\% \text { of } \\
\text { berry } \\
\text { number }\end{array}$ & $\begin{array}{c}\% \text { of } \\
\text { berries } \\
\text { per class }\end{array}$ & $\%$ \\
\hline Top & 3.4 & 47.7 & 16.9 & 44.4 & 16.1 & 42.5 & 6.6 & 39.2 & 43.0 \\
\hline Middle & 2.4 & 33.8 & 12.9 & 34.0 & 14.9 & 39.3 & 7.5 & 44.4 & 37.7 \\
\hline Bottom & 1.4 & 18.5 & 8.3 & 21.6 & 6.9 & 18.2 & 2.7 & 16.4 & 19.3 \\
\hline Sum & 7.2 & & 38.1 & & 37.9 & & 16.8 & & 100 \\
\hline
\end{tabular}

TABLE 2

Berry weight and coefficient of variation for each category size and rachis position $(\mathrm{n}=911)$.

\begin{tabular}{|c|c|c|c|c|c|c|c|c|}
\hline \multirow[t]{2}{*}{ Size category } & \multicolumn{2}{|c|}{1} & \multicolumn{2}{|c|}{2} & \multicolumn{2}{|c|}{3} & \multicolumn{2}{|c|}{4} \\
\hline & mean & c.v. & mean & c.v. & mean & c.v. & mean & c.v. \\
\hline Rachis position & g & $\%$ & g & $\%$ & $\mathrm{~g}$ & $\%$ & g & $\%$ \\
\hline Top & 0.87 & 12 & 1.30 & 11 & 1.75 & 8 & 2.24 & 8 \\
\hline Middle & 0.83 & 16 & 1.28 & 12 & 1.74 & 8 & 2.28 & 9 \\
\hline Bottom & 0.87 & 10 & 1.30 & 11 & 1.74 & 8 & 2.26 & 9 \\
\hline Mean & 0.86 & 13 & 1.29 & 11 & 1.74 & 8 & 2.26 & 8 \\
\hline
\end{tabular}

TABLE 3

Relative proportion (\%) of skin, seeds and flesh for each rachis position and berry size category $(\mathrm{n}=911)$. The coefficient of variation is determined for each category size for skin, seeds and flesh.

\begin{tabular}{|c|c|c|c|c|c|c|c|c|c|c|c|c|c|c|c|}
\hline Size category & \multicolumn{3}{|c|}{1} & \multicolumn{3}{|c|}{2} & \multicolumn{3}{|c|}{3} & \multicolumn{3}{|c|}{4} & \multicolumn{3}{|c|}{ Mean } \\
\hline Rachis position & skin & $\begin{array}{c}\text { seeds } \\
\%\end{array}$ & flesh & skin & $\begin{array}{c}\text { seeds } \\
\%\end{array}$ & flesh & skin & $\begin{array}{c}\text { seeds } \\
\%\end{array}$ & flesh & skin & $\begin{array}{c}\text { seeds } \\
\%\end{array}$ & flesh & skin & $\begin{array}{c}\text { seeds } \\
\%\end{array}$ & flesh \\
\hline Top & 23.6 & 4.0 & 72.4 & 20.1 & 4.0 & 75.9 & 18.5 & 4.4 & 77.1 & 17.6 & 4.2 & 78.2 & 19.4 & 4.2 & 76.4 \\
\hline Middle & 20.4 & 4.3 & 75.3 & 20.8 & 3.9 & 75.3 & 19.0 & 4.1 & 76.9 & 18.9 & 4.0 & 77.1 & 19.7 & 4.0 & 76.2 \\
\hline Bottom & 22.3 & 4.6 & 73.1 & 21.8 & 3.7 & 74.5 & 20.1 & 3.9 & 76.0 & 19.1 & 4.4 & 76.5 & 20.8 & 3.9 & 75.2 \\
\hline Mean & 22.3 & 4.2 & 73.5 & 20.7 & 3.9 & 75.4 & 19.0 & 4.2 & 76.8 & 18.5 & 4.1 & 77.4 & 19.8 & 4.1 & 76.1 \\
\hline \pm c.v. & 27.0 & 40.1 & 9.1 & 20.9 & 41.6 & 6.4 & 15.3 & 30.1 & 4.1 & 14.2 & 23.2 & 3.5 & 19.8 & 34.5 & 5.6 \\
\hline
\end{tabular}

proportion, irrespective of the weight category, but displayed a high coefficient of variation.

The regression analysis showed that rachis position had only a slight effect, and significant differences were obtained for only four of the thirteen variables analysed. In contrast to results found with Pinot noir (Trought et al., 1997), berry position on the rachis affected the berry weight:berry volume ratio (Table 4), skin mass (Table 5), soluble solids (Kasimatis et al., 1975; Tarter \& Keuter, 2005) and skin area:berry volume ratio (Table 6).

Consequently, at our determined range of classes, berry weight, berry volume, berry pulp, skin mass and skin area varied with size category and are not discussed further because this result was as expected (Tables 4 and 5). Berry volume, berry weight:berry volume ratio (Table 4) and skin mass (Table 5) showed an interaction between rachis position and category size; rachis position effect on berry volume was not significant and it is interesting to note the distribution per class along the rachis. Naturally, berry volume increased from the $1^{\text {st }}$ to the $4^{\text {th }}$ berry size category $(0.74,1.18,1.59$ and $2.09 \mathrm{~cm}^{3}$ respectively for classes $1,2,3$ and 4 ). The smallest and the biggest berries in terms of volume were located in the middle part of the bunch (Fig. 1).

The higher berry weight:berry volume ratio for the smallest berries and for the middle part of the bunch indicates more concentrated berries (Fig. 2).

In agreement with many researchers, seed weight increased more than proportionally to berry weight, obviously due to the increase in seed number from the smallest to the largest berries (from 1.14 to 2.93; Table 7) (Olmo et al., 1946; Cawthon \& Morris, 1982; Di Lorenzo et al., 1991; Boselli et al., 1995; Ummarino \& Di Stefano, 1996; Trought et al., 1997; Glynn \& Boulton, 2001; Roby \& Matthews, 2004; Walker et al., 2005; Barbagallo et al., 2011).

In contrast to what was found by Ummarino and Di 
TABLE 4

Results of regression analysis for the berry parameters $(n=911)$ : berry weight, berry volume, berry weight:berry volume, pulp weight.

\begin{tabular}{|c|c|c|c|c|c|c|c|c|}
\hline \multirow{2}{*}{$\begin{array}{l}\text { Variables } \\
\\
\text { Source }\end{array}$} & \multicolumn{2}{|c|}{$\begin{array}{c}\text { Berry weight } \\
(\mathrm{g})\end{array}$} & \multicolumn{2}{|c|}{$\begin{array}{l}\text { Berry volume } \\
\qquad\left(\mathrm{cm}^{3}\right) \\
\end{array}$} & \multicolumn{2}{|c|}{$\begin{array}{c}\text { Berry weight:berry } \\
\text { volume } \\
\left(\mathrm{g} / \mathrm{cm}^{3}\right) \\
\end{array}$} & \multicolumn{2}{|c|}{$\begin{array}{c}\text { Pulp weight } \\
\text { (g) }\end{array}$} \\
\hline & F ratio & $\mathrm{p}$ & F ratio & $\mathrm{p}$ & F ratio & $\mathrm{p}$ & F ratio & $\mathrm{p}$ \\
\hline Rachis position (R.P.) & 2.131 & 0.119 & 1.350 & 0.265 & 6.586 & 0.009 & 0.630 & 0.533 \\
\hline Size - category (linear) & 5453 & 0.000 & 931 & 0.000 & 13.465 & 0.000 & 4424 & 0.000 \\
\hline R.P. ${ }^{*}$ Size - category & 1.957 & 0.142 & 2.571 & 0.018 & 3.844 & 0.003 & 0.655 & 0.520 \\
\hline
\end{tabular}

TABLE 5

Results of regression analysis for the berry parameters measured $(\mathrm{n}=911)$ : seeds, single seed mass, skin mass, skin area.

\begin{tabular}{|c|c|c|c|c|c|c|c|c|c|c|}
\hline \multirow{3}{*}{$\begin{array}{l}\text { Variables } \\
\text { Source }\end{array}$} & \multicolumn{4}{|c|}{ Seeds per berry } & \multirow{2}{*}{\multicolumn{2}{|c|}{$\begin{array}{c}\text { Single seed mass } \\
(\mathrm{g})\end{array}$}} & \multirow{2}{*}{\multicolumn{2}{|c|}{$\begin{array}{c}\text { Skin mass } \\
(\mathrm{g})\end{array}$}} & \multirow{2}{*}{\multicolumn{2}{|c|}{$\begin{array}{c}\text { Skin area } \\
\left(\mathrm{cm}^{2}\right)\end{array}$}} \\
\hline & \multicolumn{2}{|c|}{ (g) } & \multicolumn{2}{|c|}{ (n) } & & & & & & \\
\hline & $F$ ratio & $\mathrm{p}$ & F ratio & $\mathrm{p}$ & $\mathrm{F}$ ratio & $\mathrm{p}$ & $F$ ratio & $\mathrm{p}$ & F ratio & $\mathrm{p}$ \\
\hline Rachis position (R.P.) & 0.576 & 0.562 & 0.441 & 0.644 & 0.113 & 0.893 & 3.805 & 0.023 & 0.254 & 0.775 \\
\hline Size - category (linear) & 520 & 0.000 & 516 & 0.000 & 0.266 & 0.606 & 861 & 0.000 & 339 & 0.000 \\
\hline R.P.*Size - category & 0.408 & 0.665 & 0.191 & 0.826 & 0.649 & 0.523 & 5.473 & 0.004 & 0.387 & 0.679 \\
\hline
\end{tabular}

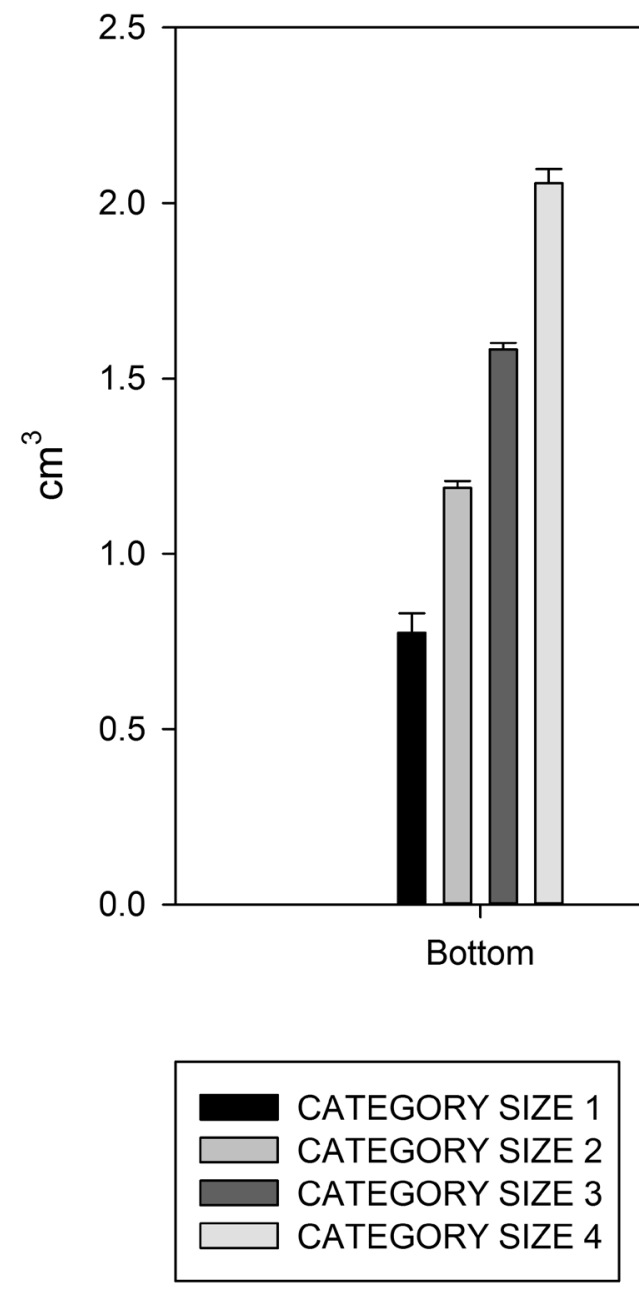

FIGURE 1

Average of berry volume in the four berry size categories as a function of the position on the rachis. Vertical lines represent standard errors. 
Stefano(1996), single seed weight did not change significantly with berry size (Table 5). Differences in skin mass (g) were also found along the rachis, and berries from the bottom area of the bunch seemed to have the heaviest skin $(0.322 \mathrm{~g}, \pm$ 0.01 s.e. $)$ compared to berries from the middle $(0.318 \mathrm{~g}, \pm$ 0.01 s.e. $)$ and the top areas $(0.301 \mathrm{~g}, \pm 0.01$ s.e. $)$. Even for this parameter, bottom and top positions showed a lower coefficient of variation $(25.2 \%$ and $26.3 \%$, respectively) than that of the middle position (29.5\%). Different bunch exposure and berry development in the respective bunch areas may have contributed to these findings. Moreover, skin mass increased by $42 \%$ from class 1 to class $2,22.2 \%$ from class 2 to class 3 , and $27.3 \%$ from class 3 to class 4 (Fig. 3 ).

In accordance with what is generally observed, larger berries had more flesh compared to skin than smaller berries (Table 3) (Matthews \& Nuzzo, 2007; Barbagallo et al., 2011). Consequently, skin area was affected by berry weight, increasing from small to large berries and displaying larger differences between classes 1 and 2, in comparison with classes 3 and 4 (Table 7).

Skin mass:skin area ratio also appeared to increase from the top to the bottom bunch area (data not shown), and from the smallest to the largest berries (Table 7). Highest skin mass per unit of skin area was found in the largest berries

TABLE 6

Results of regression analysis for the berry parameters measured $(n=911)$ : skin mass:skin area ratio, skin:pulp ratio, skin area:berry volume ratio and soluble solids.

\begin{tabular}{lcccccccc}
\hline Variables & $\begin{array}{c}\text { Skin mass:skin area } \\
\text { ratio }\left(\mathrm{g}: \mathrm{cm}^{2}\right)\end{array}$ & $\begin{array}{c}\text { Skin:pulp ratio } \\
(\mathrm{g} / \mathrm{g})\end{array}$ & $\begin{array}{c}\text { Skin area:berry volume } \\
\left(\mathrm{cm}^{2}: \mathrm{cm}^{3}\right)\end{array}$ & $\begin{array}{c}\text { Soluble solids } \\
\left({ }^{\circ} \text { Brix }\right)\end{array}$ \\
\hline Source & F ratio & $\mathrm{p}$ & F ratio & $\mathrm{p}$ & F ratio & $\mathrm{p}$ & F ratio & $\mathrm{p}$ \\
Rachis position (R.P.) & 1.986 & 0.138 & 1.050 & 0.350 & 2.026 & 0.025 & 7.244 & 0.001 \\
Size - category (linear) & 81 & 0.000 & 58 & 0.000 & 288 & 0.000 & 220 & 0.000 \\
R.P. *Size - category & 2.668 & 0.070 & 1.850 & 0.158 & 1.397 & 0.124 & 2.943 & 0.053 \\
\hline
\end{tabular}

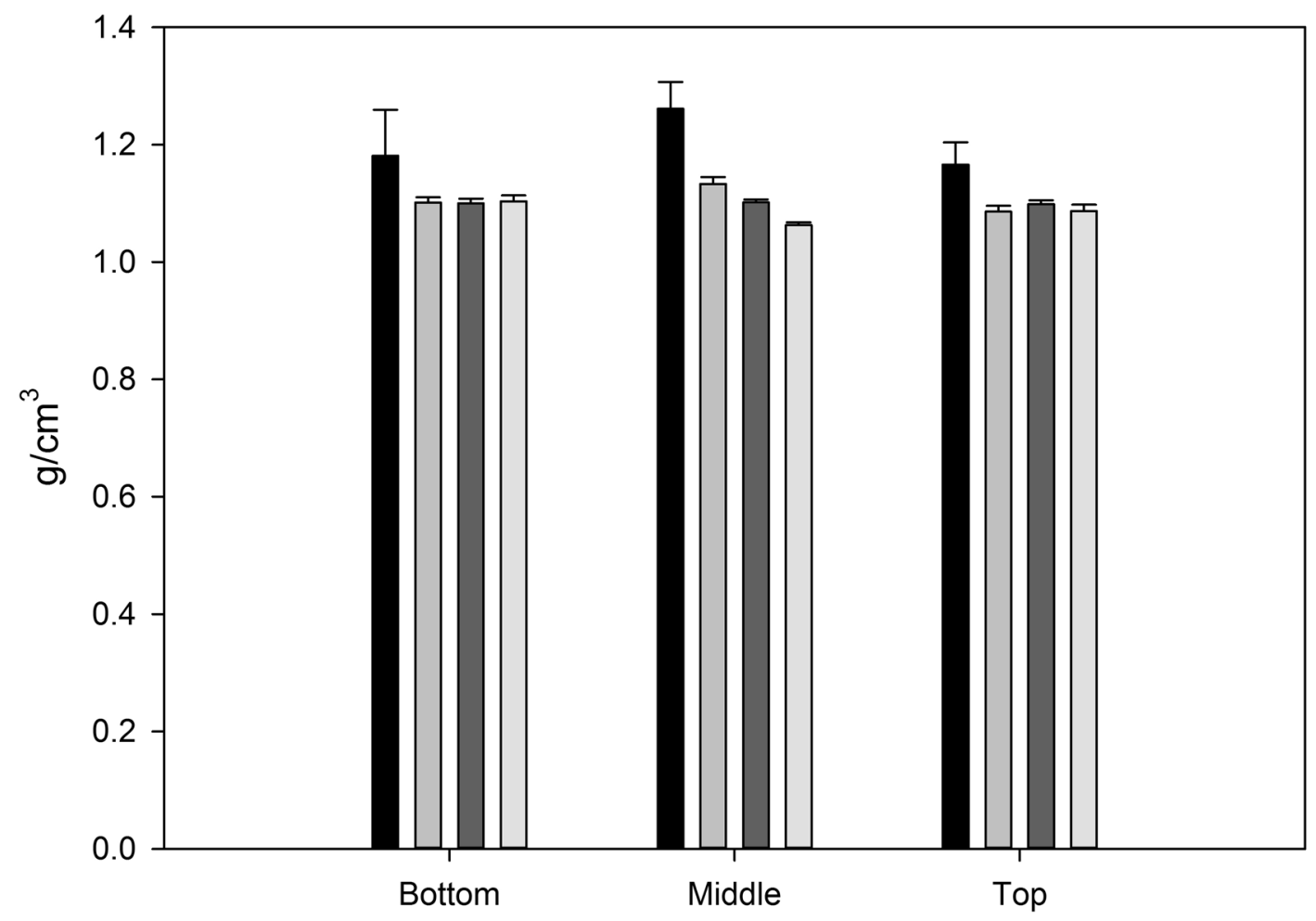

Part of Bunch

CATEGORY SIZE 1

CATEGORY SIZE 2

CATEGORY SIZE 3

CATEGORY SIZE 4

FIGURE 2

Average of berry weight $(\mathrm{g})$ :berry volume $\left(\mathrm{cm}^{3}\right)$ ratio in the four berry size categories as a function of the position on the rachis. Vertical lines represent standard errors. 


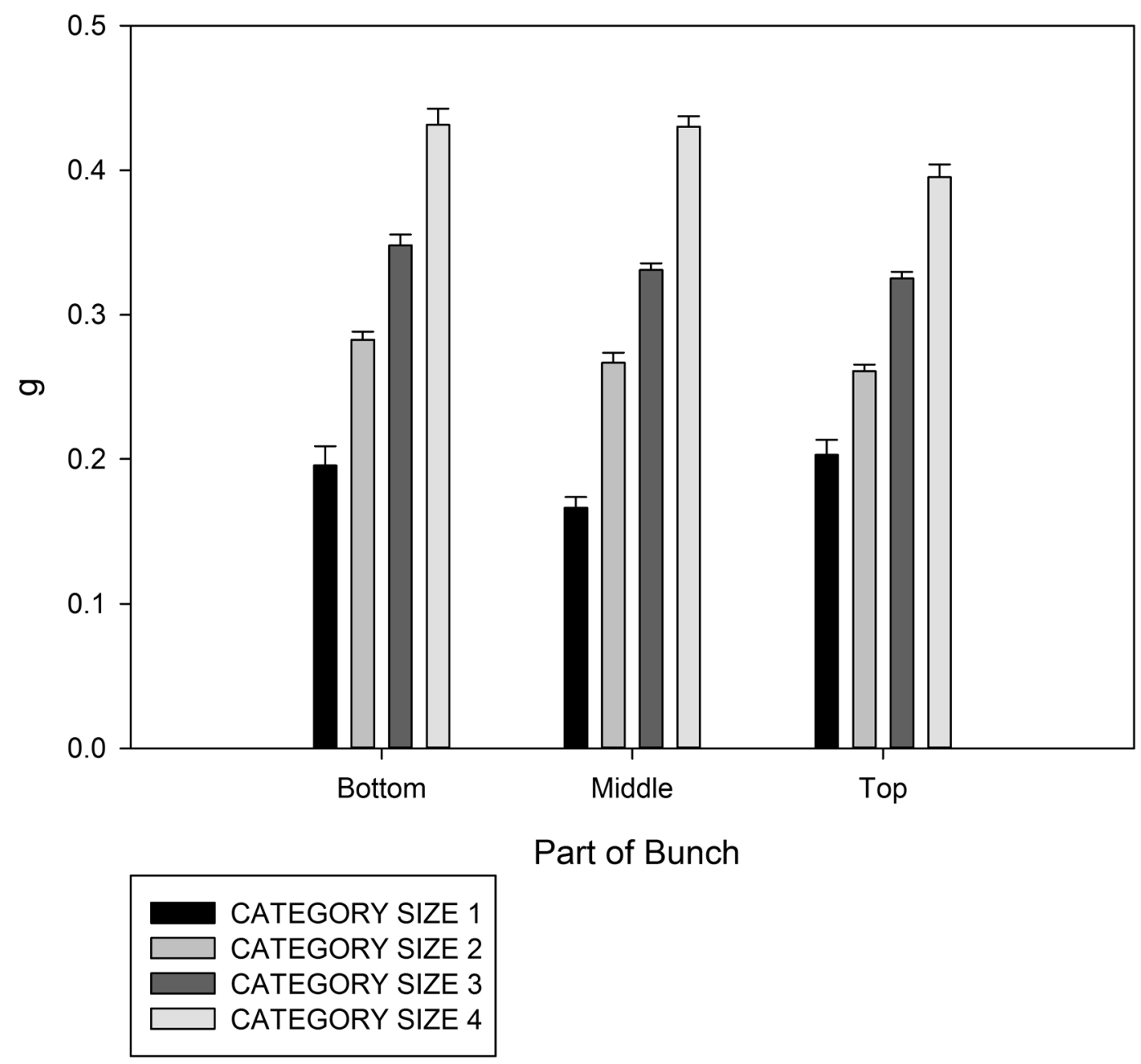

FIGURE 3

Average of skin weight of a single berry in the four berry size categories as a function of position on the rachis. Vertical lines represent standard errors.

TABLE 7

Berry parameters as a function of berry size.

\begin{tabular}{cccccccccccccccc}
\hline Parameters & \multicolumn{3}{c}{ Seed weight } & \multicolumn{2}{c}{ Seed number } & \multicolumn{2}{c}{ Skin surface } & \multicolumn{2}{c}{ Skin FW/S } & \multicolumn{2}{c}{ Skin/pulp } & \multicolumn{3}{c}{ Skin S/BV } & \multicolumn{2}{c}{ Soluble Solids } \\
& mean & s.e. & mean & s.e. & mean & s.e. & mean & s.e. & mean & s.e. & mean & s.e. & mean & s.e. \\
\hline Size category & $\mathrm{g}$ & \pm & $\mathrm{n}$ & \pm & $\mathrm{cm}^{2}$ & \pm & $\mathrm{g} / \mathrm{cm}^{2}$ & \pm & $\mathrm{g} / \mathrm{g}$ & \pm & $\mathrm{cm}^{2} / \mathrm{cm}^{3}$ & \pm & Brix & \pm \\
1 & 0.03 & 0.00 & 1.14 & 0.05 & 3.74 & 0.12 & 0.05 & 0.00 & 0.31 & 0.01 & 5.25 & 0.21 & 30.54 & 0.27 \\
2 & 0.05 & 0.00 & 1.55 & 0.04 & 4.70 & 0.05 & 0.06 & 0.00 & 0.28 & 0.00 & 3.97 & 0.06 & 29.16 & 0.13 \\
3 & 0.07 & 0.00 & 2.23 & 0.04 & 5.36 & 0.05 & 0.06 & 0.00 & 0.25 & 0.00 & 3.41 & 0.04 & 27.94 & 0.11 \\
4 & 0.09 & 0.00 & 2.93 & 0.06 & 5.90 & 0.07 & 0.07 & 0.00 & 0.24 & 0.00 & 2.82 & 0.03 & 26.83 & 0.10 \\
\hline
\end{tabular}

$\mathrm{FW}=$ Fresh weight; $\mathrm{S}=$ Skin surface; $\mathrm{BV}=$ Berry volume

(class 4). Classes 2 and 3 did not differ significantly, while class 1 had the lowest value (Table 7). Moreover, relative skin mass (expressed as percentage of the whole berry) increased from the top part of the bunch to the bottom part (19.4\%, 19.7\% and 20.8\%, respectively) (Table 3 ).

Skin mass $(\mathrm{g})$ :berry pulp $(\mathrm{g})$ ratio was negatively related to berry fresh weight (Table 7). The skin surface $\left(\mathrm{cm}^{2}\right)$ :berry volume $\left(\mathrm{cm}^{3}\right)$ ratio (Table 7$)$ would result in a higher impact of the skin for smaller berries during contact with the must during fermentation, creating a different and likely more favourable medium for wine quality, depending on the condition of the grapes during harvest and on the volume of the juice (solvent) (Hunter et al., 2004; Matthews \& Nuzzo, 2007; Barbagallo et al., 2011).

Berry position along the rachis affected the soluble solids content (Fig. 4). Several researchers (Nelson et al., 1963; Nelson \& Richardson, 1967) have found a wide distribution of soluble solid values within single bunches of "Thompson Seedless" table grapes, but they did not compare the variation for different cluster areas. Weaver and Ibrahim 


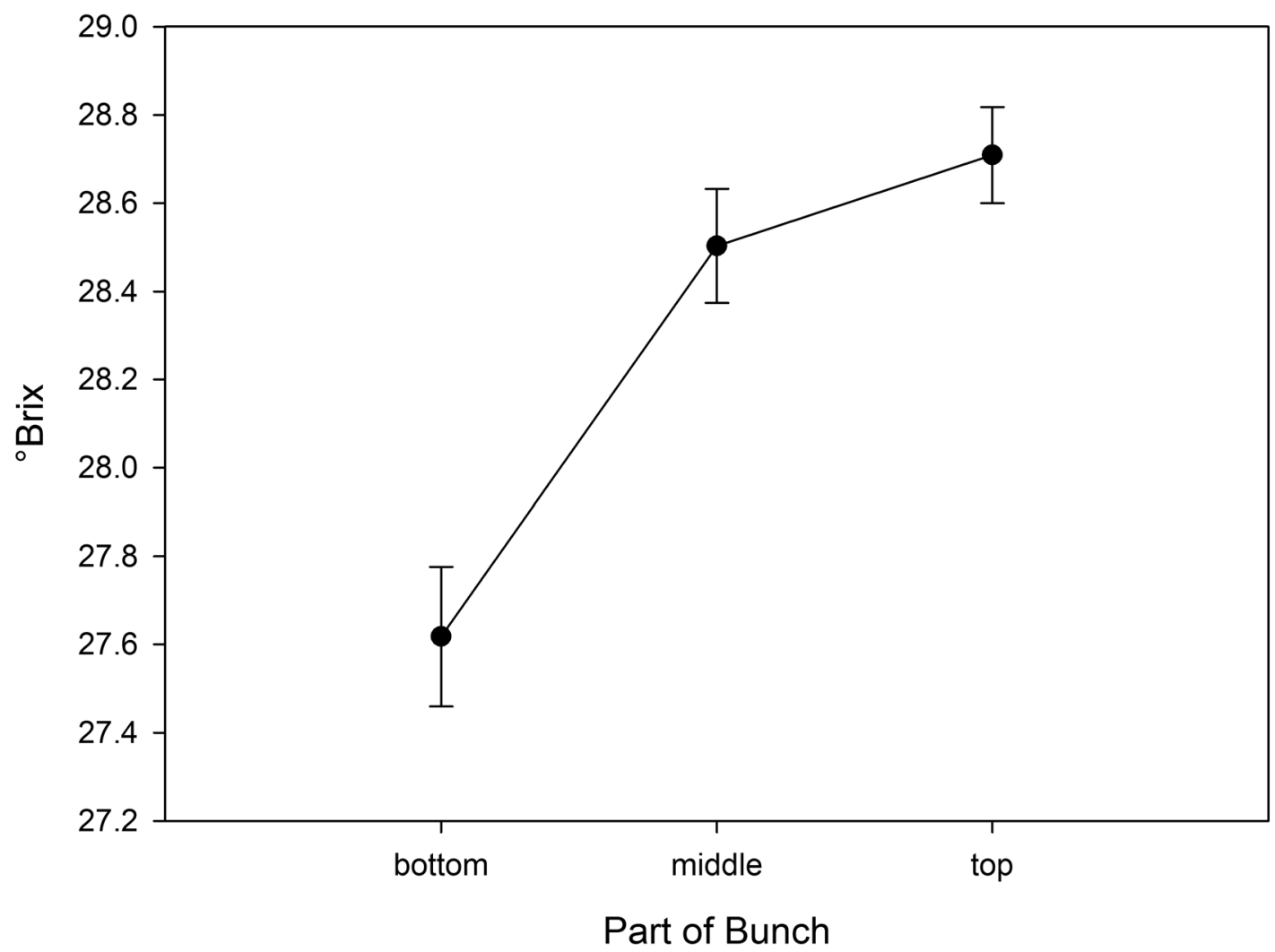

FIGURE 4

Soluble solids ( ${ }^{\circ}$ Brix) at different positions on the rachis. Vertical bars represent standard errors.

(1968) divided mature bunches of Thomson Seedless grapes into five equal parts from apex to base. They found that all the portions of the bunch had approximately the same percentage of soluble solids, with no significant differences between them. Trought et al. (1997) also found no significant difference in soluble solid content along the rachis of Pinot noir and Cabernet Sauvignon bunches. In contrast, Kasimatis et al. (1975) found a significantly lower ${ }^{\circ} \mathrm{B}$ in berries from the bottom area and a significantly higher ${ }^{\circ} \mathrm{B}$ in the apical area compared to that in the central area. Tarter and Keuter (2005) indicated that, with respect to percentage of soluble solids, significant differences among berries can exist regionally within a cluster of Cabernet Sauvignon. They suggested that sugar sampling is best confined to the top region of a bunch. In this study, Shiraz berries showed significant differences in terms of soluble solids along the rachis (Table 6), having a higher level in the shoulder to middle bunch area $\left(28.7^{\circ} \mathrm{B}\right.$ and $28.6^{\circ} \mathrm{B}$ respectively) than in the bottom area $\left(27.6^{\circ} \mathrm{B}\right)$. With reference to the average of total soluble solids, differences were $-0.81,+0.12$ and +0.28 respectively, for the bottom, middle and shoulder areas (Fig. 4), with similar coefficient of variation values $(8.0 \%, 7.6 \%$ and $7.5 \%$ in the middle, bottom and shoulder areas respectively).

Sugar content per berry seemed proportional to size (Roby \& Matthews, 2004; Barbagallo et al., 2011), whereas the concentration was negatively related. The sugar concentration value decreased approximately $12 \%$ from smaller to larger berries (Table 7).

\section{CONCLUSIONS}

The position of the berry on the rachis had no consistent effect on berry size, but affected soluble solid concentration and skin mass. Higher soluble solid values were found in the top part of the bunch. After categorising the entire population of berries into four weight categories, only a small fraction of the total berry population was found in the smallest and largest weight categories. Most berries were in the 1.01 to $2.0 \mathrm{~g}$ range. Heterogeneity in ripeness level among berries may depend upon the variety. It is extremely difficult to obtain uniform berry size and composition under field conditions, even when all vineyard management practices are properly executed. Since berry variation may have a negative impact on wine quality and on the consistency of wine style, continuous efforts are required to reduce variation.

\section{LITERATURE CITED}

Baker, G.A., Amerine, M.A. \& Roessler, E.B., 1965. Characteristics of sequential measurements of grape juice and must. Am. J. Enol. Vitic. 16, 21-8.

Barbagallo, M.G., Guidoni, S. \& Hunter, J.J., 2011. Berry size and qualitative characteristics of Vitis vinifera L. cv. Syrah. S. Afr. J. Enol. Vitic. 32(1), 129-136.

Boselli, M., Volpe, B. \& Di Vaio, C., 1995. Effect of seed number per berry on mineral composition of grapevine (Vitis vinifera L.) berries. J. Hort. Sci. $70(3), 509-515$.

Carbonneau, A., Moueix, A., Leclair, N. \& Renoux, J.L., 1991. Proposition of a berry sampling method based on analysis of maturation heterogeneity within a plant. Bull. O.I.V. 727-728, 679-690. 
Cawthon, D.L. \& Morris, J.R., 1982. Relationship of seed number and maturity to berry development, fruit maturation, hormonal changes, and uneven ripening. J. Am. Soc. Hort. Sci. 107, 1097-1104.

Coombe, B.G., 1987. Distribution of solutes within the developing grape berry in relation to its morphology. Am. J. Enol. Vitic. 38, 120-127.

Di Lorenzo, R., Barbera, M., Costanza, P., Pisciotta, A., Santangelo, T. \& Barbagallo, M.G., 2007. Sampling strategy and minimum sample size to judge correct determination of grape maturity. Intervitis Interfructa. Messe Stuttgart 20-22, 169-176.

Di Lorenzo, R., Sottile, I., Occorso, G., Barbagallo, M.G., Iannolino, G. \& Nuccio, A., 1991. Prove di irrigazione dell'uva da tavola in Sicilia. Simposio Internazionale sulle uve da mensa. Bari, Palermo 26-31 August 1991.

Fernandez, L., Pradal, M., Lopez, G., Berud, F., Romieu, C. \& Torregrosa L., 2006. Berry size variability in Vitis vinifera L. Vitis 45(2), 53-55.

Glynn, M. \& Boulton, R., 2001. Spatial distribution of Brix, phenolic compounds, berry weight and seed number within a Cabernet Sauvignon cluster. Abstr. ASEV 52 ${ }^{\text {nd }}$ annual meeting, June 2001, San Diego, California. p. 9 .

Gray, J., 2006. The basis of variation in the size and composition of Shiraz berries. In: Oag, D., DeGaris, K., Partridge, S., Dundon, C., Francis, M., Johnstone, R. \& Hamilton. R. (eds). 'Finishing the job' - optimal ripening of Cabernet Sauvignon and Shiraz. Australian Society of Viticulture and Oenology, Adelaide. pp. $30-35$.

Greenspan, M., 2005. Taming fruit variability. Wine business monthly, December 15. Available: www.winebusiness.com

Hunter, J.J., Archer, E. \& Volschenk, C.G., 2010. Vineyard management for environment valorization. Proc. VIII Int. Terroir Congr., June 2010, Soave, Italy. 2 (7), pp. 3 - 15.

Hunter, J.J., Pisciotta, A., Volschenk, C.G., Archer, E., Novello, V., Deloire, A. \& Nadal, M., 2004. Role of harvesting time/optimal ripeness in zone/ terroir expression. Joint International Conference on Viticultural Zoning, November 2004, Cape Town, South Africa. pp. 466 - 478.

Kasimatis, A.N., Vilas, E.P., Jr., Swanson, F.H. and Baranek, P.P., 1975. A study of the variability of 'Thompson Seedless' berries for soluble solids and weight. Am. J. Enol. Vitic. 25, 37-42.

Matthews, M.A. \& Nuzzo, V., 2007. Berry size and yield paradigms on grapes and wine quality. In Proc. Int. Workshop on Advances in Grapevine and Wine Research. Acta Hortic. 754, 423-436.

Matthews, M.A., Cheng, G. \& Weinbaum, S.A., 1987. Changes in water potential and dermal extensibility during grape berry development. J. Amer. Soc. Horticult. Sci. 112, 314-319.

Nelson, K.E. \& Richardson, H.B., 1967. Relationship between flavor and maturity in consumer acceptance of Thompson Seedless. Blue Anchor 44(2), 23-25.

Nelson, K.E., Baker, G.A., Winkler, A.J. Amerine, M.A., Richardson, H.B. \& Jones, F.R., 1963. Chemical and sensory variability in table grapes Hilgardia 34, 1-42.
Olmo, H.P., 1946. Correlation between seed and berry development in some seeded varieties of Vitis vinifera. Am. Soc. Hort. Sc. 48, 291-297.

Pisciotta, A., Abruzzo, F., Barbagallo, M.G. \& Di Lorenzo, R., 2010. Effetti della dimensione degli acini sui parametri qualitativi nella cv Cabernet Sauvignon. Italus Hortus 17(3), 520-524.

Pisciotta, A., Abruzzo, F., Barbagallo, M.G., Santangelo, T. \& Di Lorenzo, R., 2012. Ulteriori approfondimenti degli effetti della dimensione degli acini sulla qualità dell'uva nella cv Cabernet Sauvignon. Italus Hortus 3(1), 82-88.

Poni, S., Bernizzoni, F., Civardi, S. \& Libelli, N., 2008. Effects of prebloom leaf removal on growth of berry tissues and must composition in two red Vitis vinifera L. cultivars. Australian J. of Grape and Wine Research $15,185-193$.

Roby, G. \& Matthews, M., 2004. Relative proportions of seed, skin and flesh, in ripe berries from Cabernet Sauvignon grapevines grown in a vineyard either well irrigated or under water deficit. Aust. J. Grape and Wine Res. 10, 74-82

Shaulis, N.J., 1956. The sampling of small fruit for composition and nutritional studies. J. Am. Soc. Hort. Sci. 68, 576-86.

Smart, R., 1985. Principles of grapevine canopy management microclimate manipulation with implications for yield and quality. Am. J. Enol. Vitic. 36(3), 230-239.

Soil Classification Working Group, 1991. Soil Classification: a Taxonomic System for South Africa. Memoirs on the Agricultural Resources of South Africa No. 15. Department of Agricultural Development, Pretoria, pp. 257.

Sousa de Melo, M.S., 2011. Berry size implication for phenolic composition and wine quality of Vitis vinifera L. cv. Syrah. Master's thesis, Euromaster Vinifera, Montpellier, Geisenheim.

Tarter, M.E. \& Keuter, S.E., 2005. Effect of rachis position on size and maturity of Cabernet Sauvignon berries. Am. J. Enol. Vitic. 56(1), 86-89.

Tarter, M.E. \& Keuter, S.E., 2008. Shoot-based sampling of Vitis vinifera clusters. Am. J. Enol. Vitic. 59(1), 55-60.

Trought, M., Tannok, S. \& Harkness, E.M., 1997. Berry size and soluble solids variation within a bunch of grapes. Proc. 4th Int. Symp. Cool Climate Vit. and Enol. PLACE? pp. $70-73$.

Ummarino, I. \& Di Stefano, R., 1996. Influenza del numero di semi per acino sulla composizione dell'uva. Riv. Vitic. Enol. 4, 29-37.

Walker, R.R., Blackmore, D.H., Clingeleffer, P.R., Kerridge, G.H., Rühl, E.H. \& Nicholas, P.R., 2005. Shiraz berry size in relation to seed number and implications for juice and wine composition. Aust. J. Grape and Wine Res. 11, 2-8.

Weaver, R.J. \& Ibrahim, M.I., 1968. Effect of thinning and seededness on maturation of Vitis vinifera L. grapes. Proc. Am. Soc. Sci. 92, 311-322.

Zeeman, A.S., 1981. Oplei. In: Burger, J. \& Deist, J. (eds). Wingerdbou in Suid-Afrika. ARC Infruitec-Nietvoorbij, Private Bag X5026, 7599 Stellenbosch, South Africa. pp. 185 - 201. 